DOI: https://doi.org/10.3126/njdrs.v15i0.31592

\title{
Assessing Climate Change Adaptation Strategies of Rural People in Nepal
}

\author{
Bishista Shree \\ Lecturer, Tri-Chandra Multiple Campus \\ Email for correspondence: urbis_yes@yahoo.com
}

\begin{abstract}
This paper presents climate change adaptation strategies applying by the rural people living around Chedaguard Municipality ward no. 6 of Jajarkot district. Both qualitative and quantitative approaches were used in the survey and further data were obtained through focus group discussions, case study and participant observations techniques. In doing so, the fous was given to agriculture based livelihoods including forest, water resources, health sector, energy and natural land reform practices. Likewise, changing pattern of rainfall, temperature, humidity were analyzed. Existence of new diseases on agriculture, water resource dryness, forest degradation, forest fire, etc. has been explored resulting with degradation of agricultural production and productivity

To adapt from the climate change of this impact, local people have been using Jeevatu, Sisnu, Titepati, Banmara, Khirro, etc. as a bio-pesticides. Similarly, people have used improved cooking stoves to protect forest and they have done plantation to overcome the water resources scarcity.
\end{abstract}

Key words: Climate change, adaptation strategies, rural people, rural livelihood

\section{Introduction}

Climate change adaptation is an opportunity for social reform, for the questioning of values that drives inequalities in development and our unsustainable relationship with the environment. It is not only important to understand the impact of climate change but also necessary to formulate adaptation strategies to neglect the effect of climate change. According to Intergovernmental Panel on Climate Change (IPCC), "Climatechange refers to change in the state of the climate that can be identified by changes in the mean and/or the variability of its properties and that persists for an extended period, typically decades or longer". It means changes in climatic pattern in extended period of time of particular geographical area due to natural as well as anthropogenic activities. "Climate change refers to a change of climate that is attributed directly or indirectly to human activity that alters the composition of the global atmosphere and that is inaddition to natural climate variability observed over comparable time periods (UNFCCC).

Climate change is any long term significant change in the "average weather" that a region experience. Average weather may include temperature, precipitation, and wind patterns. Climate change is the shifting of average climatic patterns over many years in fact at least over 30 years of time. United Nations Framework Convention on Climate Change (UNFCCC, 1992) in article-1 defines "climate change" as: "a change of climate which is attributed directly or indirectly to human activity that alters the composition of the global atmosphere and which is in addition to natural climate variability observed over comparable time periods." 
Despite its relatively small area, Nepal has very diverse climatic conditions, ranging from tropical in the south to alpine in the north. The diversity in Nepal's climate is matched by the diversity of its multiple ecosystems, floral and faunal species. The livelihoods of over 70 percent of all Nepalese are based on agriculture and forest resources. It is clear that climate change has major implications for Nepal's ability to produce food for its population. The results of global climate scenario modeling suggest that the impacts of climate change may be intense at high elevations and in regions with complex topography, as is the case in Nepal's mid-hills. Shrestha et al., (1999) has mentioned that temperatures are increasing in Nepal and that rainfall is becoming more variable. A decade later, in 2009, a modeling exercise conducted by team of Nepali, American, British, Pakistani and Bangladeshi experts (NCVST, 2009) mentioned that precipitation is likely to be more uncertain and that storm intensity will increase, which is due to the climate change and it also shows how vulnerable Nepal is in accordance with climate change.

Recurring climate related natural hazards undermine agriculture productivity causing poverty and food insecurity. Agriculture dependent livelihood activities are frequently exposed to a variety of recurring natural disasters such as floods, landslides, snow avalanches, Glacial Lake Outburst Floods (GLOF), hailstorms, thunderstorms, cold waves, heat waves, drought, epidemics and earthquake. In particular floods, landslides, hailstorms and drought spells are almost regular phenomena. Outbreaks of disease and pests in plant and animal are another area of concern although their widespread occurrences are not so frequent. Changing hydrological flows both due to glacial retreat and increased and more variable precipitation will impact on many irrigation systems, water-powered grain mills, hydropower plants and drinking water supply systems throughout the country. This will affect agricultural production and water and sanitation, leading to increasing levels of malnutrition and incidence of water-borne disease. The most vulnerable to climate change are the poor and marginalized who generally are the least able to cope with disasters, live in areas most at risk to hazards and generally have the least information, knowledge and resources to reduce their risk. The predicted impacts of climate change will heighten existing vulnerabilities, inequalities and exposure to hazards and will therefore impact the most on those the least able to cope. It is found that, precipitation is growing more erratic, days are becoming hotter, pattern of winds, fog and hailstorms have altered and that farmers are becoming more vulnerable. A review of adaptation research confirms their view, identifying Nepal as particularly likely to experience fluctuations in climate (ISET, 2008).

Nepal's National Adaptation Programme of Action (NAPA) prepared in 2010 also recognizes that climate will be uncertain and vulnerability will increase Recent research has helped bring about a better understanding of adaptation. It is increasingly seen as adjustments in ecological, social, and economic systems in response to actual or expected climatic stimuli and their effects or impacts. Adaptation is now recognized as much more than coping. In well-adapted systems, people actually "do well" despite changing conditions, including those attributable to climate change (ISET, 2008).

Agriculture is the human enterprise that is most vulnerable to climate change. Tropical agriculture, particularly subsistence agriculture is more vulnerable, as smallholder farmers do not have adequate resources to adapt to climate change. While agroforestry may play a significant role in mitigating the atmospheric accumulation of greenhouse gases (GHG), it also has a role to play in helping smallholder farmers adapt to climate change. In this paper, we examine data on the mitigation 
potential of agroforestry in the humid and sub-humid tropics. We then present the scientific evidence that leads to the expectation that agroforestry also has an important role in climate change adaptation, particularly for small holder farmers. We conclude with priority research questions that need to be answered concerning the role of agroforestry in both mitigation and adaptation to climate change (Verchot, et al., 2007).

Nepal hosts some of the most spectacular natural areas and biodiversity in the world (Table 1). Home to the planet's highest peak, Nepal also boasts 118 ecosystems, 75 categories of vegetation, and 35 types of forest. These resources are increasingly at risk. The people of Nepal, particularly the rural poor, are directly dependent on natural resources for survival, and a significant portion of Nepal's economy comes from climate-sensitive industries such as agriculture, forestry, and eco-tourism. As a result of both the considerable biodiversity and economic and geographic profile, Nepal is ranked 13th in the world in terms of climate change vulnerability (Climate Change Risk Atlas, 2012).

Table 1. Climate Vulnerable Index of Different District of Nepal

\begin{tabular}{|c|c|}
\hline $\begin{array}{l}\text { Vulnerability } \\
\text { Ranking }\end{array}$ & Districts \\
\hline $\begin{array}{l}\text { VeryHigh }(0.787- \\
1.000)\end{array}$ & $\begin{array}{l}\text { Kathmandu, Ramechhap.Udayapur,Lamjung, Mugu, } \\
\text { Bhaktapur, Dolakha, Saptari,Jajarkot }\end{array}$ \\
\hline $\begin{array}{l}\text { High }(0.601- \\
0.786)\end{array}$ & $\begin{array}{l}\text { Mahottari, Dhading, Taplejung, Siraha, Gorkha, Solukhambu, } \\
\text { Chitwon, Okhaldhunga,Acham, Manang, Dolpa,Kalikot, } \\
\text { Khotang,Dhanusa,Dailekh, Parsa,Salyan }\end{array}$ \\
\hline $\begin{array}{l}\text { Moderate }(0.356- \\
0.600)\end{array}$ & $\begin{array}{l}\text { Sankhuwasabha,Baglung, Sindhuli, Bhojpur, Jumla, Mustang, } \\
\text { Rolpa, Bajahang, Rukum, Rautahat, Panchthar, Parbat, Dadeldhura, } \\
\text { Sunsari, Doti, Tanahu, Makawanpur,Myagdi,Humla,Bajura,Baitadi,Bara, } \\
\text { Rasuwa,Nawalparasi, Sarlahi, Sindhupalcjok, Darchula,Kaski }\end{array}$ \\
\hline $\operatorname{Low}(0.181-0.355)$ & $\begin{array}{l}\text { Nuwakot, Dhankuta,Kanchanpur,Bardiya, Kapilbastu, } \\
\text { Terhathum, Gulmi, Pyuthan, Surkhet, Arghakhanchi, Morang, } \\
\text { Dang,Lalitpur, Kailali, Syanja, Kavrepalanchok }\end{array}$ \\
\hline $\begin{array}{l}\text { Very Low }(0.000- \\
0.180)\end{array}$ & Ilam, Jhapa,Banke, Palpa, Rupandehi \\
\hline
\end{tabular}

(MoE/NAPA Project, 2010)

Nepal is more vulnerable to the effects of climate change due to its high dependence of climate-sensitive sectors such as glaciers, agriculture and forestry, and its low financial adaptive capacity. Agriculture is affected the most when drought adversely impacts rain-fed agriculture, largely in developing countries where the majority of farmers practice subsistence agriculture. Based on FAO's approach of climate smart agriculture which combines the three dimensions of sustainable development (Economic, social \& environmental) for an integrated approach to climate adaptation, resilience and food security, ICIMOD has developed climate smart village approach, which is customized for mountain areas which equips communities with tools to improve their 
resilience to climate changes and fosters sustainable development, particularly of agriculture. This study tries to analyze what kinds of adaptation practices are available to the farmers of Ward no. 6 , Chedaguard Municipality of Jajarkot district and whether the practices are effective to the people to withstand climatic stress or not. It is expected that research results will be helpful to the organization in providing new adaptation practices against climate change and further improving in livelihood of local peoples by reducing vulnerabilities of community at the local level.

\section{Methodology}

This study assessed the impact of climate change on local livelihood and also highlighted ongoing adaptation strategies applied by the farmers to minimize the impact of climate change and maximize resiliency. The primary data were collected through household survey questionnaire, focus group discussion, case study and observation techniques. Similarly secondary data were collected from the published books, articles as well as published and unpublished reports related to research issues. More specifically, out of the 512 households, using Arkin and Colton formula, 62 households were taken as sample numbers and 3 case studies were done for collecting primary data. Focus group discussion was conducted at field level. DHM data were taken to analyze the climatic trend of Jajarkot. Adaptation strategies of the local people were learnt through interviewand questionnaire.

\section{Results and Discussions: Social Demography}

From the study, it was found that 80 percent of respondents were women. The majority of respondents i.e. 42 percent were in the age of 20-29 years. In Suwanauli 65 percent of respondents were Brahmin/Chhetri and others are Dalits. 94 percent of people follow Hinduism whereas 6 percent of them were Christian. In the study, it was found that 68 percent of people were dependent on agriculture, while 9 percent on the government services, 10 percent on labor work, 9 percent had their own business, 1 percent lived a retire life and 3 percent of them were unemployed. 95 percent of the respondents were known about the climate change and its impacts.

\section{Historical Timeline}

Historical timelines were done with the full participation of local people and from this major hazards with the events caused were found in the study. Hazards like drought, land slide; flood, drought, forest fire, disease on animals, human and livestock are increasing day by day in Suwanauli village (Table 2). 
Table 2. Historical TimeLine

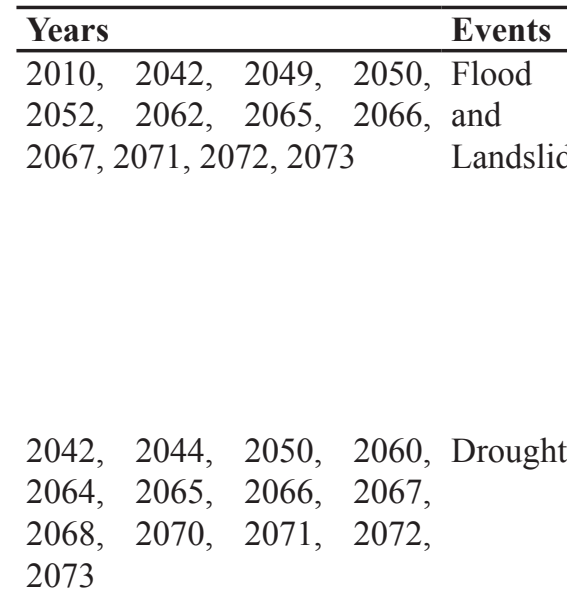

2030, 2042, 2055, 2059, Fire 2063, 2065, 2068, 2069, 2070, 2072, 2073

2035, 2053, 2068, 2063, Disease 2064, 2066, 2067, 2070, on 2072, 2073 animals

2041, 2044, 2060, 2064, Disease 2065, 2066, 2067, 2068, on 2070, 2071, 2072, $2073 \quad$ agriculture 2036, 2045, 2050, $2066 \quad$ Diseases on Human Casualties In 2010, 25 people were died due to landslide, 7 household were destroyed and many properties were destroyed. From the flood and landslide many irrigated field were destroyed, forest resources were destroyed near Jamintakura, In 2050, 3 hectare of fertile land and 3 house were taken away by landslide, many livestocks and property were loss due to landslide and flood in this area. Stored crops were washed away by flood in the village.

Due to the drought many crop land is become barren, crops were destroyed by drought, water resources dried out, water resources of Sirumuhan, ghodepatal, tirkhuwa, pasila, Siling, dawaura, ghattekhola, wolyawat, khoriya khola, kalekhola, jadipani, khadka tole, etc were dried out and only little water flow from it. Its difficult for villagers to grow crop and drink safe water.

In 2030, 3 people died, 9 household and 32 livestock were died due to fire. Similarly in 2036, 1 person died due to fire and 1 house was destroyed. Likewise in 2063, 15 hectare of forest were destroyed and in 2065, 20 hectare of forest were destroyed by fire. In the summer season fire causes lots of destruction in human and property.

The disease like Khoret, Enderodometas disease on goats, frog disease on ox, mouth infection of buffalos, diarrhea in animals, etc has cause lots of animal deads in the village.

Disease like, sindure, gabaro, Maize root destruction, ants on potatoes, insects on rice, paddy etc. destroy all the crops nowadays. And only 30percent were harvested in comparison to previous.

\begin{tabular}{ll}
$\begin{array}{l}\text { on } \\
\text { Human }\end{array}$ & $\begin{array}{l}\text { Few years ago disease like stomach pain, measles, di- } \\
\text { arrhea etc. killed many people in the village. But now } \\
\text { it is becoming less due to care on health and sanita- } \\
\text { tion. }\end{array}$ \\
\hline
\end{tabular}

(Field Survey, 2017)

\section{Seasonal Calendar}

The monsoon period has been decreasing nowadays compared to 20-30 years back. Before, the monsoon period started from Jestha 2nd week and ended in Asoj 2nd week but now monsoon starts from Ashad 2nd week and ends in Bhadra, the intensity of rainfall is higher than before which creates 
the landslide, flood and crop destruction. Likewise the number of months carrying autumn season is increasing whereas the length of cold season is decreasing. Before, the cold season used to exist from Asoj to Falgun 2nd week while now the cold season exists from Mangsir to Magh. Summer season is also in expansive trend. Before itoccurred from Chaitra to Shrawan while now itoccurs from mid Falgun to Bhadra. Before few years, the snow falls used to take place in the higher hills of Suwanauli but now a day it is difficult to see the snow. Likewise, the length of foggy season is also decreasing nowadays. Before, there were less hailstorms but nowadays there are hailstorms in Baishak. These all symptoms show that there is a gradual effect of the change in climate in the recent years (Table 3).

Table 3. Seasonal Calendar

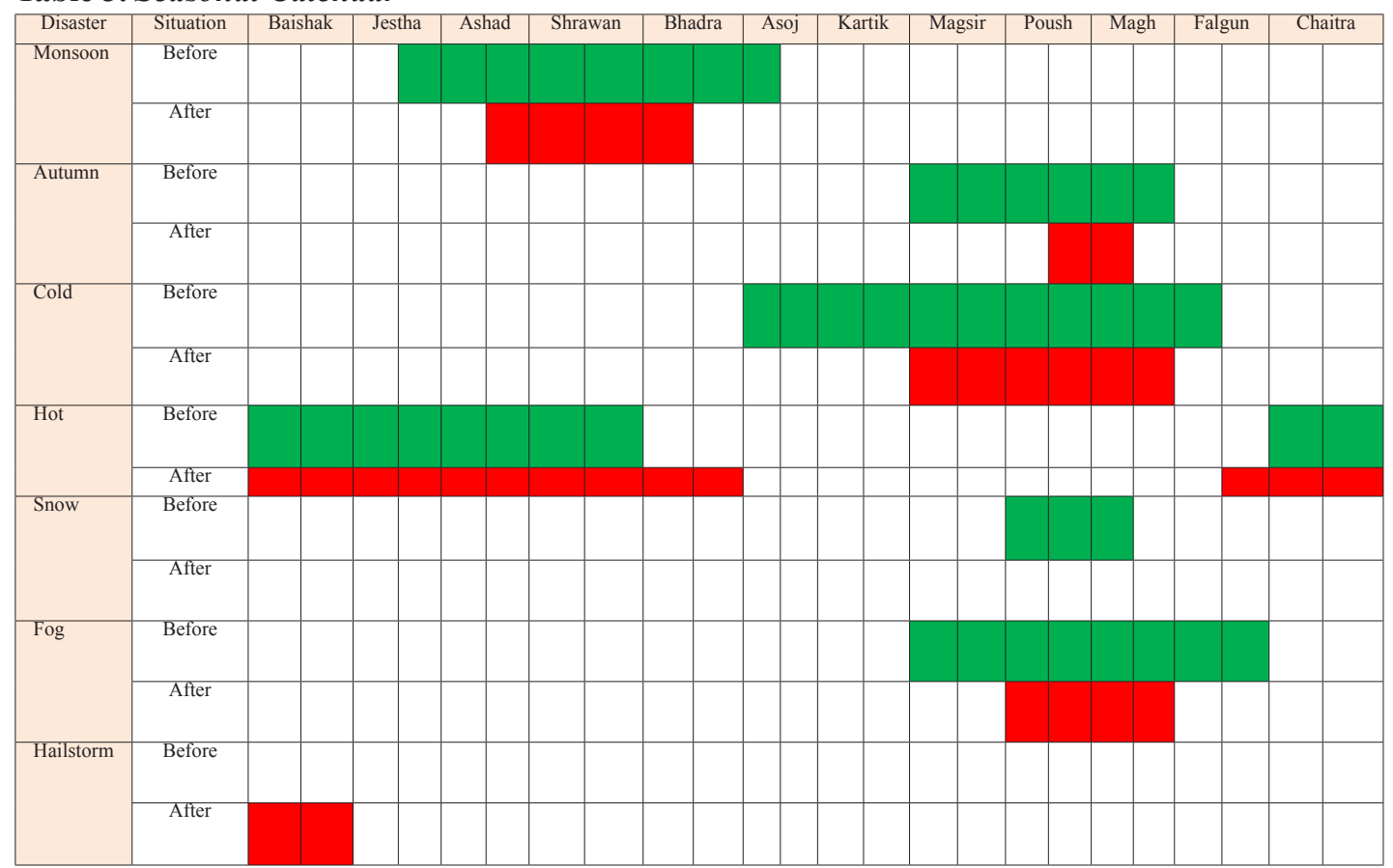

(Field Survey, 2017)

\section{Temperature and Rainfall Trend}

Since past 30 years all most all the people have been feeling the increase in temperature. About 85 percent of the respondents claimed that the temperature was increasing mainly in summer and agreed that the summer was getting hotter year by year. 8 percent of the respondents denied the increment of the temperature, 2 percent claimed that it was decreasing and 5 percent respondents claimed that they had no idea about it. Similarly, 60 percent of respondents said that the length of winter period was decreasing and it was getting colder than past whereas 25 percent of the respondent perceived that temperature was increasing in winter. 12 percent of the population told that there was no change in temperature and only 3 percent of the respondents had no idea of the temperature change.

Before few years, the snow falls used to take place in the higher hills of Suwanauli but now we do not get to seeit. Likewise, foggy weather is also decreasing nowadays. Before there used to be fewer 
hailstorms but nowadays there are hailstorms in Baishak. It shows that there is the change in climate in the recent years. Change has been found in the rainfall pattern as well; intensity of rainfall is higher in the rainy season. Heavy rainfall is in increasing pattern however the duration is decreasing. 85 percent of respondents claim that they feel the heavy rain during rainy season, as all their crops get destroyed by rain. Only 1 percent of respondents do not see the change in rainfall pattern while 4 percent accepts the fact as the rainfall decreasing and 10 percent has no idea on it. Similarly, 90 percent of respondent said that it was an unusual rain, 4 percent of respondents have felt decreasing and the rests have no idea on rainfall.

Various disasters like landslide, soil erosion, flood, drought, water resource decrease, forest fire, livestock diseases, disease on agriculture, hailstorm etc. occur due to climate change. In the ranking, drying of water resource comes in the 1st position causing lack of water for irrigation which is followed by livestock diseases, drought, landslide and diseases in agriculture in the second, third, fourth and fifth position respectively. Besides, river bank cutting, hailstorm, fires are also the simultaneous disasters induced by climate change. Climate change also causes irregular rainfall and increase in temperature which lead to the destruction of main sources of water. 90 percent respondents said that main sources of drinking water had been destroyed. 89 percent of the respondents claim that new epidemic diseases have been seen these days than before. 6 percent of respondents claim that there is less disease than before but 5 percent of respondents did not answer.

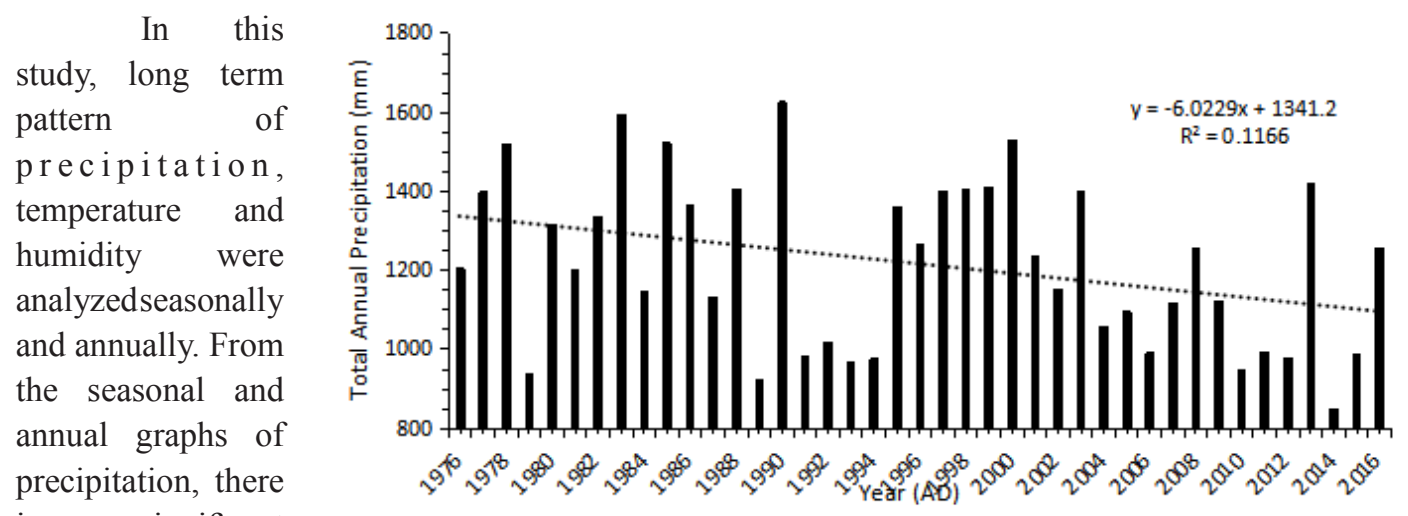

is significant

decrease in the Figure 1. Annual Precipitation (1976 to 2016) at Chaurjahari, Rukum summer and winter

rainfall precipitation trend. Summer rain fall is decreasing with the rate of $2.49685 \mathrm{~mm} /$ year and winter rainfall is decreasing with the rate of $0.5146 \mathrm{~mm} /$ year. Rainy days are decreased but the intensity of rainfall is increasing. The summer rainfall is decreasing rapidly than the winter rainfall.

In 37 years, statistical record of the maximum temperature is decreasing slightly and the minimum temperature is increasing. From this the overall temperature of the study area is increasing every year. In summer maximum temperature is increasing but the winter temperature is decreasing. From this, what we can understand is hotter days are getting hotter while colder days are getting colder year by year. From this pattern the whole jajarkot district is somehow impacted from the temperature 
fluctuation. Although rainfall is in decreasing trend, the annual and seasonal humidity is in slightly increasing trend. It is may be due to the decreasing trend in maximum temperature. In overall, there is no significant change in the humidity.

\section{Climate Change Adaptation Strategies}

The farmers are applying different adaptation strategies particularly in irrigation sector, water resource management, agriculture production, forest resource management, energy management, health sector and natural resource management. All the strategies are briefly presented below:

For irrigation system. Rural people are adopting different strategies to adapt the climate change. People are practicing drip irrigation, rain water harvesting by making pond, making water irrigation canal, health awareness training, capacity development training, distribution of seed varieties, vaccinated livestock practice, hybrid livestock, IPM technologies, tunnel for vegetable farming, etc.

For water resource management. In the village, people were facing scarcities of water for drinking, cooking and irrigation and also for feeding for livestock before. But these days people are focusing on protecting watershed areas, plantation, storage of rain water and running the project for tap water supply with the support of government and non- government organizations.

For agriculture production. More than 80 percent of people are now using the hybrid/ resistant seeds in agriculture to adapt the changing climate. Only 20 percent of people are found using the traditional type of seeds. According to the villagers, the organizations which give training about the agriculture and livelihood provide the hybrid seeds and also teach about resistant strategies to different types of ants and bacteria. Little fertilizer is enough to grow this type of agricultural crops which almost enlarge the productivity doubled than before. Plastic ponds, green manure, drip irrigation system, tunnel system, intregreted pest management (IPM) etc. were seen effective in the study area. Bio-pesticide was prepared and used for pest which was prepared by using locally available bitter and sour tasting plants. Cow and buffalo's urine, water and Jeevatu. Sisnu, Titepati, Banmara, Khirro, etc. are commonly used for the preparation of bio-pesticide which controls pests without any side effect.

Forest resources management. Now people are using improved cooking stove (ICS) for cooking, large grassland areas have been changed to protected areas and handed over to the local community as a community forest. Protection, preservation and plantation of trees lead conserving nature and natural resources. Different training and awareness programs encourage local people to conserve forest. People are now aware about conserving biodiversity as they are making the fire line to conserve forest and using it in a planned manner. District forest office along with Nepal Climate Change Support Program (NCCSP) have given different forest management training to local people and have made fire line to tackle the forest fire.

For energy management. Previously firewood was the only source of the local people for energy. Health issues from smoke and time consuming phenomena for collecting firewood were the common issues before but now 91 percent of the people are found using improved cooking stove (ICS) in the village, whereas only 8 percent and 1percent respectively are depending on traditional cooking stove and Petroleum Gas (LPG) in Suwanauli, Jajarkot. The changing pattern of energy consumption, with the technical and financial support of different government and non-government organizations, found enlarging the efficiency of work, better health condition, reducing the amount of traditional firewood consumptions and saving time for doing other works. According to Mrs. Bimala Singh Giri 
(Social Mobilizer), villagers were happy after installation of ICS in their home as the consumption of wood product is reduced to half than before and health issues is also less than before which was caused by smoke. Female get enough time to do other works. With the use of ICS, people experience 95 percent less smoke than traditional cooking stove. According to them, they light bulbs from micro hydropower and piko hydropower in the village, bring changes in the overall energy consumption pattern which plays the crucial role for copping against climate change.

For health sector. Changing pattern of health issues and health care system is another concerned sector of climate change and its adaptation. New kinds of diseases like fever, unknown diarrhea, and other physiological changes are experienced by the local people. Before few years people were not aware about these diseases and cure. But now people are concerned more about their health and timely treatment. Provision of health care organization like health posts, awareness campaigns about health, hygiene and sanitation as well as health insurance policy are becoming more effective in this regards.

For natural disaster management. Land slide and soil erosion are the common natural calamities that people have been facing but the trend of such disasters has been increasing every years. It has been found that natural disaster like landslide, soil erosion; flood, etc. directly affect the livelihood of local people. To cope with such disasters people are using gabion wall in the flood and landslide prone areas and planting trees and conserving them near the disaster prone area as well. 76 percent of respondents said that they had managed landslide which occurred near their crop land, near house and road side by using the gabion wall and plantation of trees like bamboo, amrisho, etc. and only around one fourth population were found without any preventive measures applying for climate change adaptation as well.

\section{Conclusion}

This study came up with conclusion that rural people living around Suwanauli village are now becoming aware about climate change and its impact on agriculture based livelihood. They are well known about decreasing trend of monsoon period but increasing trend of rainfall that is creating landslide, flood and crop destructions. This is in fact outcomes of capacity and skill development training such as forest management training; agricultural trainings on crop rotation, crop varieties, using organic fertilizers and pesticides, proper use chemical fertilizers, pesticides and insecticides provided by government and non-government mechanism. Rural people of Suwanauli village are thus abled to apply climate change adaptation strategies for improving their livelihood. And collectively managing irrigation system, water resources, agriculture production system, forest resources, household energy, health hazards and natural disasters in order to minimize negative impact of climate change on their agriculture based livelihoods.

\section{References:}

Adger, W. N. (2003). Social aspects of adaptive capacity. In J. B. Smith, R. J. T. Klein \& S. Huq (Eds.), Climate change, adaptive capacity and development (29-50). London: Imperial College Press.

Agrawal, A. (1999). Greener pastures. Durham: Duke University Press. 
Bartlett, R., Bharati, L., Pant, D., Hosterman, H. \& McCornick, P. (2010). Climate change impacts and adaptation in Nepal. Colombo, Sri Lanka: International Water Management Institute (Working Paper 139). doi:10.5337/2010.227

Blaikie, P., Cannon, T., Davis, I. \& Wisner, B. (1994). At risk: Natural hazards, People's vulnerability, and disaster. London: Routledge Publication.

Bonfils, C. G., Anderson, B. D., Santer, T. J., Phillips, K. E., Taylor, M., Cuntz, M. D., Zelinka, P., Marvel, K. B. I., Cook, B. I., Cvijanovic, I. \& Durack, P. J. (2017). Competing influences of anthropogenic warming, ENSO, and plant physiology on future terrestrial aridity. Journal of Climate, 30(7), 6883-6904, doi:10.1175/JCLI-D-17-0005.1.

Eun-Soon I. M., Jeremy, S. P. \& Elfatih A. B. (2017). Deadly heat waves projected in the densely populated agricultural regions of South Asia.

Handmer, J. (2003). Adaptive capacity: what does it mean in the context of natural hazards? In J. B. Smith, R. J. T. Klein \& S. Huq (Eds.), Climate change, adaptive capacity and development (51-70). London: Imperial College Press.

Ministry of Popualtion and Environment .(MoPE). (2004). Initial national communication to the conference of parties of UNFCCC. Kathmandu: Government of Nepal.

IPCC (2007). Climate change 2007: Impacts, adaptation and vulnerability. In M. L. Parry, O. F. Canziani, J. P. Palutikof, P. J. van der Linden \& C. E. Hanson, (Eds.), Contribution of working group II to the fourth accessment report of the intergovernmental panel on climate change (976). UK: Cambridge University Press.

IPCC (2014). Climate change 2014: Impacts, adaptation and vulnerability. UK: Cambridge University Press.

Joel, B., Smith, R., Klein, J. T. \& Huq, S. (nd.). Climate change, adaptive capacity and development.

Kelly, P., \& Adger, N. (2000). Theory and practice in assessing vulnerability to climate change and facilitating adaptation. Climatic Change, 47(4), 325-352.

Klein, R. J. T., \& Smith, J. B. (2003). Enhancing the capacity of developing countries to adaptation to climate change: A policy relevant research agenda. In J. B. Smith, R. J. T. Klein \& S. Huq (Eds.), Climate change, adaptive capacity and development (317-334). London, UK: Imperial College Press.

Lebel, L. (2012). Local knowledge and adaptation to climate change in natural resource-based societies of the Asia Pacific. Mitigation and Adaptation Strategies for Global Change, 1-20.

Leichenko, R., \& O’Brien, K. L. (2002). The dynamics of rural vulnerability to global change: The case of Southern Africa. Mitigation and Adaptation Strategies for Global Change, 7(1), 1-18.

Louis, V., Verchot, M., Noordwijk, V., Kandji, S., Tomich, T., Ong, C., Albrecht, A., Mackensen, J., Bantilan, C., Anupama, K. V. \& Palm, C. (2007). Climate change: Linking adaptation and mitigation through agroforestry. Mitigation and Adaptation Strategies for Global Change, 12(5), 901-918.

Macchi, M., Gurung, A. M., Hoermann, B. \& Choudhary, D. (2011). Climate variability and Change in the Himalayas: Community perceptions and responses. Kathmandu: International Centre for Integrated Mountain Development. 
Manandhar, S., Vezt, D. S., Perret, S. R. \& Kazama, F. (2011). Adapting cropping systems to climate change in Nepal: A cross-regional study of farmers' perception and practices. Regional Environmental Change, 11(2), 335-348.

McGregor, J. (1994). Climate change and involuntary migration: Implications for food security. Food Policy, 19(2), 120-32.

Ministry of Environment (MoE). (2010). National adaptation programme of action. Singha Durbar, Kathmandu: Government of Nepal.

NASA (2017). Goddard institute report for Space studies.

Nayava, J. L. (1981). Climates of Nepal and their implications to agricultural development (Unpublished $\mathrm{PhD}$ thesis, Australian National University). Canberra, Australia: Deaprtment of Agriculture and Environment Science.

Nepal Climate Vulnerability Study Team (NCVST). (2009). Vulnerability through the eyes of vulnerable: Climate change induced uncertainties and Nepal's development predicaments. Kathmandu: Institute for Social and Environmental Transition-Nepal (ISET-Nepal), and Institute for Social and Environmental Transition (ISET) Boulder, Colorado.

Niamir, M. (1995). Indigenous systems of natural resource management among pastoralists of arid and semi-arid Africa. London: Intermediate Technology Publications Ltd.

Pachauri, R. K. (1992). Global warming: Impacts and implications for South Asia. In J. Schmandt \& Clarkson, J. (Eds.), The regions and global warming: impacts and response strategies (7990). New York: Oxford University Press.

Purvis, N., \& Busby, J. (2004). The security implications of climate change for the UN system. New York: Brookings.

Regmi, B. R., \& Adhikari, A. (2007). Climate Change and human development-risk and vulnerability in the warming world; Country case study in Nepal. Human Development Report, Biodiversity, Research and Development (LI-BIRD).

Shrestha, A. B., Wake, C. P., Mayewski, P. A. \& Dibb, J. E. (1999). Maximum temperature trends in the Himalaya and its vicinity: An analysis based on temperature records from Nepal for the Period 1971-94. Journal of Climate, 12, 2775-2786.

Silva, R. A., West, J. J., Lamarque, J. F., Shindell, D. T., Collins, W. J., Faluvegi, G., Folberth, G. A., Horowitz, L. W., Nagashima, T. Naik, V., Rumbold, S. T., Sudo, K., Takemura, T., Bergmann, D., Cameron-Smith, P., Doherty, R. M., Josse, B., MacKenzie, I. A., Stevenson, D. S. \& Zeng, G. (2017). Future global mortality from changes in air pollution attributable to climate change. Journal of Nature Climate. Change. doi:10.1038/nclimate3354.

Smit, B. \& Pilifosova, O. (2003). From adaptation to adaptive capacity and vulnerability reduction. In J. B. Smith, R. J. T. Klein \& S. Huq (Eds.), Climate change, adaptive capacity and development (9-28). London, UK: Imperial College Press.

Smit, B., \& Wandel, J. (2006). Vulnerability, adaptation and adaptive capacity. Global Environmental Change, 16(3), 282-292.

Smit, B., Burton, I., Klein, R. \& Wandel, J. (2000). An anatomy of adaptation to climate change and varia- bility. Climatic Change, 45(1), 223-251. 
Turner, B. L., Kasperson, R. E., Matson, P. A., McCarthy, J. J., Corell, R. W,. Christensen, L., Eckley, N., Kasperson, J. X., Luers, A., Martello, M. L., Polsky, C., Pulsipher, A. \& Schiller, A. (2003). A framework for vulnerability analysis in sustainability science. Proceedings of the National Academy of Sciences, 100(14), 8074-8079.

UNFCCC (1992). United nation framework on convention on climate change report. Author.

Winter, J. M., Young, C. A., Mehta, V. K., Ruane, A. C., Azarderaksh, M., Davitt, A., McDonald, J., Haden, V. R. \& Rosenzweig, C. (2017). Integrating water supply constraints into irrigated agricultural simulations of California. Environment Model. Software, 96, 335-346, doi:10.1016/j.envsoft.2017.06.048.

Yohe, G., \& Tol, R. (2002). Indicators for social and economic coping capacity moving towards a working definition of adaptive capacity. Global Environmental Change, 12(1), 25-40. 